\title{
Experimental Study on Cooling Performance Characteristics of Electric-Driven Air Conditioning System Using Two Kinds of Coolants with the Triple Fluids Heat Exchanger for Fuel Cell Electric Vehicles
}

\author{
Hoseong Lee ${ }^{1}$, Jongphil Won ${ }^{1}$, Chungwon Cho ${ }^{1}$, Taekkyu Lim ${ }^{1}$, Hanbyeol Jeon ${ }^{1}$, \\ Wonsuk Lee ${ }^{2}$, Chulmin Kim², Yongchan Kim ${ }^{* 3}$ \\ ${ }^{1}$ Thermal management $R \& D$ center, KATECH, 303 Pungse-ro,Cheonan-si, \\ Chungnam, 31214, Korea \\ ${ }^{2}$ Advanced Research team, Doowon Climate Control, 16-1, Umbongmyeon, \\ Chungnam, 336-864, Korea \\ ${ }^{3}$ Department of Mechanical Engineering, Korea University, Seoul, 136-701, \\ Korea \\ ${ }^{1}$ E-mail :leehs@katech.re.kr, ${ }^{2}$ E-mail :wslee@dwdcc.co.kr, \\ ${ }^{3}$ E-mail :yongckim@korea.ac.kr
}

\begin{abstract}
The objective of this study was to investigate the cooling performance characteristics of electric-driven air conditioning system using two kinds of coolants with triple fluids heat exchanger for a fuel cell electric vehicle. In order to analyze the cooling performance characteristics, electric-driven air conditioning system with the triple fluids heat exchanger for a fuel cell electric vehicle was developed and tested under various operating conditions according to inlet air conditions of evaporator, coolant conditions and compressor speed. The cooling capacity and coefficient of performance (COP) for cooling of tested air conditioning system were $7.0 \mathrm{~kW}$ to 2.8 under high inlet air temperature, $420 \mathrm{C}$ with the rated compressor speed, 5,000rev/min, respectively. In addition, developed triple fluids heat exchanger to transfer heat between a refrigerant and two kinds of coolants was analyzed under the same operating conditions with respect to pressure drop and heat transfer portion among two coolants. The cooling performance and efficiency of the developed electric-driven air conditioning system were thought to sufficient capacity to cope with cooling loads under various real driving conditions for a fuel cell electric vehicle.
\end{abstract}

Keywords: Electric-driven air conditioning system, Triple fluids heat exchanger, Cooling performance, COP, Fuel-cell electric vehicle

\section{Introduction}

Fossil fuel energy has been used for a long time to power vehicles with internal combustion engines. Internal combustion engines should no longer be used for public transportation and private vehicles because of the world energy crisis and global warming [1]. Because of increasing international usage regulations on fossil fuels and environmental concerns to mitigate global warming and glacier melting, many automotive companies have developed zero-emission vehicles as an alternative to the internal combustion engine (ICE). So, recently, many studies on the development of "green cars" which do not use fossil fuels are being conducted by company engineers and researchers for protection of the environment. Such vehicles have been developed by many automotive makers, although the classifications of green cars have not been officially defined internationally. In this study, green cars would be generally justified by their 
power source. Electric vehicles, fuel cell electric vehicles and hybrid electric vehicles could be widely classified to deal with environmental regulations [2-4]. Although electricdriven vehicles do not emit air pollutants, their limited driving range is a critical problem for commercialization and popularization. Recently developed electric vehicles generally have maximum driving ranges of $200 \mathrm{~km}$, but this can be reduced by over $40 \%$ when the vehicle's heating and cooling systems are operated [5-8]. The efficient heating of the cabin of an electric vehicle is a very important factor in preventing a reduction in driving range. In electric-driven vehicles, heating devices are necessary to heat the cabin air because a high heat source like the engine of conventional vehicles does not exist. Generally, an electric heater of the PTC (positive temperature coefficient) type has been used in electric-driven vehicles. An electric heater system has the advantage of low cost because it is not necessary to modify the established design and add additional devices. However, it could draw heavily from the battery due to the operation conversion characteristics of the electric PTC heater. This can result in a dramatically reduced driving range when the heater is operated. Therefore, effective heating systems for the cabins of electric-driven vehicles are required, to minimize such reductions in range.

The heat pump system has been considered as an alternative to the electric PTC heater for increasing system efficiency [9-12]. Studies on the heat pump system for conventional vehicles were initially made. Antonijevic and Heckt reported that it was superior as an automotive heating unit to other heating solutions with respect to heating performance and fuel consumption [13]. Hosoz and Direk investigated the operating characteristics of an R-134a heat pump system using an air source [14]. The tested heat pump system provided sufficient heating performance in mild weather conditions but its heating capacity dropped rapidly with a decrease in outdoor temperature. The use of an additional heating device was required for the heating load [15].

Previous studies on heat pump systems have focused on conventional vehicles using the internal combustion engine. However, there are few studies on heat pump systems with triple fluids heat exchanger between a refrigerant and two kinds of coolants for fuel cell vehicles. Therefore, electric-driven air conditioning system using triple fluids heat exchanger for cooling and heating of the cabin in fuel cell vehicles needs to be studied, with the variation of driving conditions, including inlet air temperature of the indoor heat exchangers (the evaporator for cooling, the condenser for heating), coolant conditions and compressor speeds. The cooling performance characteristics based on cooling capacity and COP (coefficient of performance) of tested electric-driven air conditioning system with developed triple fluids heat exchanger were first analyzed in this study.

\section{Experimental Setup and Data}

\subsection{Test Setup}

Figure 1 shows the schematic diagram of the basic test setup to measure the performance of coolant-sourced air conditioning system for the fuel cell electric vehicle using the triple fluids heat exchanger.

The test setup mainly consisted of an electric-driven compressor, triple fluids heat exchanger, evaporator, an expansion device (thermally operated type), and accumulator. The refrigerant path flew in the order as follows: electric-driven compressor, inner heat exchanger, (pass by EXV), triple fluids heat exchanger, (pass by 3 Way V/V to evaporator), TXV, evaporator, accumulator. The two kinds of coolants with each different temperature level passed from constant temperature baths to triple fluids heat exchanger. The test setup with triple fluid heat exchanger was installed in a psychrometric calorimeter, which provided pre-controlled ambient temperature. The psychrometric calorimeter, equipped with an air-handling unit including a cooling coil, a heating coil, and a humidifier, was set to $27{ }^{\circ} \mathrm{C} \sim 42{ }^{\circ} \mathrm{C}$ to an accuracy of $\pm 0.2{ }^{\circ} \mathrm{C}$. The psychrometric 
calorimeter was controlled by using the PID control method. Both an evaporator and a gas cooler with multi-flow type were installed in the psychrometric calorimeters for the purpose of controlling the air-side inlet conditions.

The electric-driven compressor was variable speed type and the current used to drive the compressor was measured by the power meter (WT-210). Compressor work was calculated based on the power input and current. The power input was measured exactly to evaluate the electrical air conditioning system. During the experiments, the major operating parameters were monitored graphically and numerically in real time. In order to calculate and evaluate the performance of the electrical air conditioning system the temperature, pressure, and the mass flow rate were measured. Table 1 shows the specifications of the electrical air conditioning system using two kinds of coolants for a fuel cell electric vehicle. Table 2 shows the test conditions used in this study. During the experiments, the indoor air temperature was set to $27,35,42{ }^{\circ} \mathrm{C}$ with relative humidity of $50 \%$ and the air flow rate was set to $360 \mathrm{~m}^{3} / \mathrm{hr}$.

Indoor air temperatures and air flow rates on the evaporator side of the passenger vehicle were varied from $27{ }^{\circ} \mathrm{C}$ to $42{ }^{\circ} \mathrm{C}$ and $360 \mathrm{~m}^{3} / \mathrm{hr}$, respectively. The compressor speed was set variously at $3000 \mathrm{rev} / \mathrm{min}$ to $8000 \mathrm{rev} / \mathrm{min}$. The displacement of the compressor was $33.0 \mathrm{cc} / \mathrm{rev}$. The air flow rates at the HVAC module were obtained according to the input voltages of the blower; they were $360 \mathrm{~m}^{3} / \mathrm{hr}$ at the input voltage of $10.0 \mathrm{~V}$. The above tests were performed to obtain the real air flow rates of the HVAC module for the real fuel cell electric vehicle. The HVAC module consisted of the evaporator assembly and air ventilation parts.

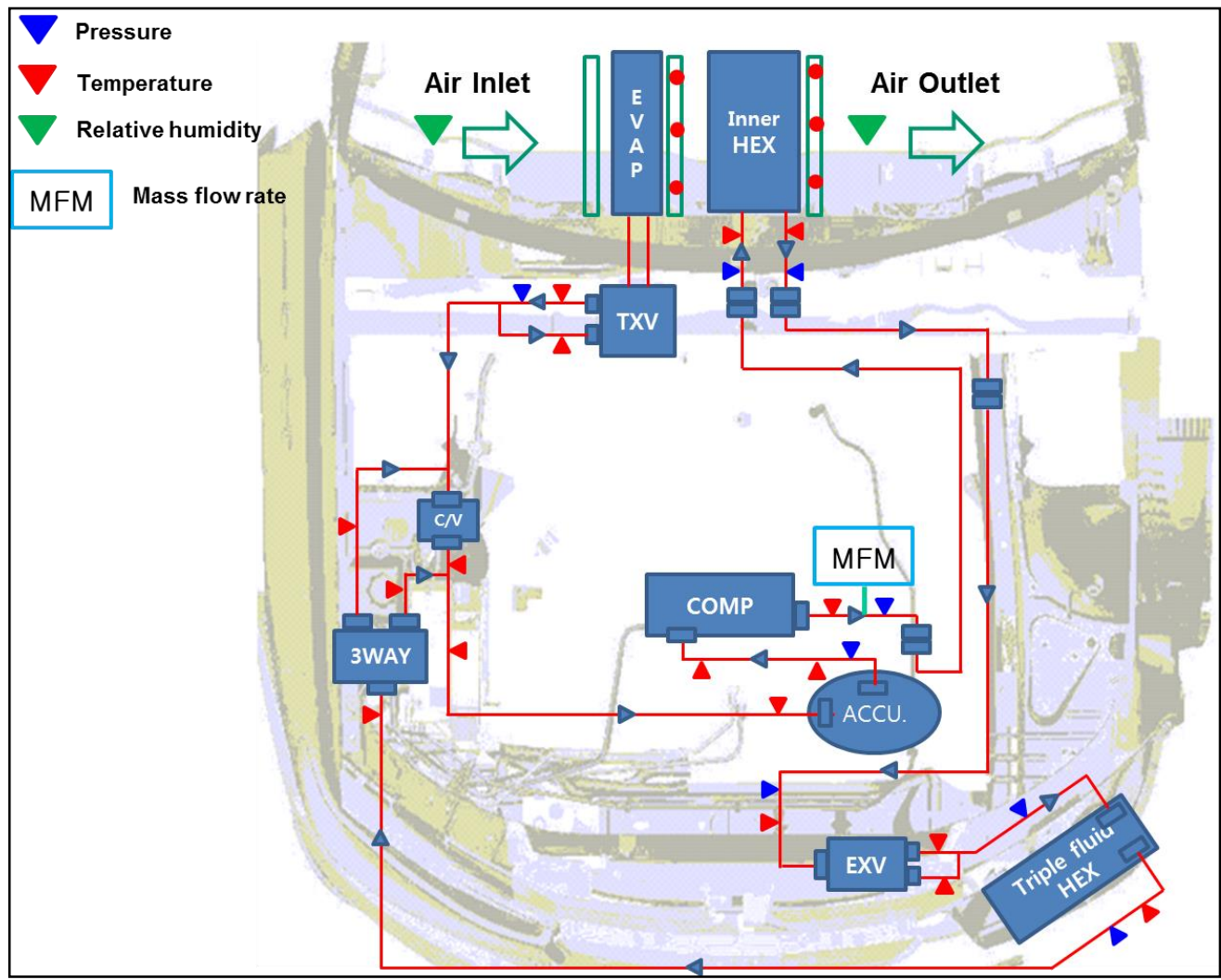

Figure 1. Schematic Diagram of the Test Setup 
Table 1. Components Specifications of Electrical Air Conditioning System Using Triple Fluid Heat Exchanger

\begin{tabular}{|c|c|c|}
\hline Components & & Specifications \\
\hline $\begin{array}{l}\text { Inner } \\
\text { Heat exchanger }\end{array}$ & $\begin{array}{c}\text { Capacity }(\mathrm{kW}) \\
\text { Type, core size }\left(\mathrm{mm}^{3}\right)\end{array}$ & $\begin{array}{l}5.5 \text { at } 6 \mathrm{~m}^{3} / \mathrm{min} \text { and } 5,000 \mathrm{rpm} \\
\text { Multi-flow type, W } 222 \times \mathrm{H} 144 \text { x D } 54\end{array}$ \\
\hline \multirow{2}{*}{$\begin{array}{l}\text { Evaporator } \\
\text { (Interior heat } \\
\text { exchanger) }\end{array}$} & Capacity (kW) & 5.0 at $6 \mathrm{~m}^{3} / \mathrm{min}$ and $5000 \mathrm{rpm}$ \\
\hline & Type, core size $\left(\mathrm{mm}^{3}\right)$ & Multi-flow type, W 273 x H 230 x D 45 \\
\hline \multirow{2}{*}{$\begin{array}{l}\text { Triple fluids } \\
\text { heat exchanger }\end{array}$} & Capacity (kW) & $\begin{array}{l}6.5 \text { at stack coolant } 60^{\circ} \mathrm{C} \text {, electric device } \\
\text { coolant } 45^{\circ} \mathrm{C} \text { and } 5000 \mathrm{rpm}\end{array}$ \\
\hline & Type, core size $\left(\mathrm{mm}^{3}\right)$ & $\begin{array}{c}\text { Count flow type, W } 190 \times \text { H } 225 \times \text { D } 80 \\
\text { Stack side : } 35 \% \text {, Electric device side : } 65 \%\end{array}$ \\
\hline \multirow{2}{*}{ Compressor } & Type & Electric driven compressor \\
\hline & Displacement (cc/rev) & 33 \\
\hline \multirow{2}{*}{$\begin{array}{l}\text { Expansion } \\
\text { valve }\end{array}$} & Type & Thermally controlled type \\
\hline & Flow rate $(\mathrm{kg} / \mathrm{h})$ & $50 \sim 250$ \\
\hline Accumulator & Volume (cc) & 950 \\
\hline
\end{tabular}

Table 2. Test Conditions

\begin{tabular}{cc}
\hline Components & Conditions \\
\hline Compressor speed $(\mathrm{RPM})$ & $3000,4000,5000,6000,7000,8000$ \\
$\mathrm{~T}_{\text {evaporator, in }}\left({ }^{\circ} \mathrm{C}\right)$ & $27.0,35.0,42.0$ \\
$\mathrm{Q}_{\text {evaporator, in }}\left(\mathrm{m}^{3} / \mathrm{hr}\right)$ & 360 \\
$\mathrm{~m}_{\text {stack coolant, in }}($ liter $/ \mathrm{min})$ & 10 \\
$\mathrm{~T}_{\text {stack coolant, in }}\left({ }^{\circ} \mathrm{C}\right)$ & 60.0 \\
$\mathrm{~m}_{\text {electric device coolant, in }}($ liter $/ \mathrm{min})$ & 10 \\
$\mathrm{~T}_{\text {electric device coolant, in }}\left({ }^{\circ} \mathrm{C}\right)$ & 45.0 \\
\hline
\end{tabular}

Table 3. Test Equipment and Uncertainty of the Experimental Parameters

\begin{tabular}{cc}
\hline Items & Accuracy \\
\hline Thermocouples (T-type) & $\pm 0.1^{\circ} \mathrm{C}$ \\
Pressure gage (Sensors, PI3H) & $\pm 0.1 \%$ (Max 250 bar) \\
Mass flow meter (Coriolis type) & $\pm 0.15 \%$, Max $680 \mathrm{~kg} / \mathrm{h}$ \\
Data logger (Gantner) & E. Gate IP (V3) (2.93W @ $12.06 \mathrm{~V})$ \\
Cooling capacity & $4.5 \%$ \\
Cooling COP & $5.8 \%$ \\
\hline
\end{tabular}


Table 3 shows the uncertainties of the parameter measurements. Refrigerant and air temperatures were measured with thermocouples. The thermocouples were calibrated to an accuracy of $\pm 0.1{ }^{\circ} \mathrm{C}$. The refrigerant flow rate was measured by a Coriolis type flow meter with an uncertainty of $\pm 0.15 \%$ and an upper limit of 680 $\mathrm{kg} / \mathrm{h}$. This flow meter was installed between the outlet tube of the internal heat exchanger and the inlet of the expansion valve to minimize the measurement errors. Pressure sensors, which can measure absolute pressure up to 30 bar with an uncertainty of $\pm 0.1 \%$, were installed at the inlet and outlet of each component. In order to verify the measured data of the cooling capacity and the cooling COP, an uncertainty analysis was performed in accordance with the $95 \%$ confidence level set by the standards of ANSI/ASME (1985) and Moffat [16,17]. The precision limits and bias limits of all the parameters associated with heating capacity and heating COP were estimated. The average uncertainties of the experimental data on cooling capacity and cooling COP were $4.5 \%$ and $5.8 \%$, respectively.

\subsection{Data Reduction}

Figure 2 shows the heat balance between the air side and the refrigerant side used in this study. The heat transfer rate of the refrigerant side was calculated by the refrigerant enthalpy method (ANSI/AMCA 210, 1985 and ASHRAE Standard 116, 1983) [18]. Equation (1) was used to calculate the refrigerant side heat transfer rate. The heat transfer rate of the air side was determined by utilizing both the air flow rate and enthalpy difference, which were calculated by Equation (2), which was used to calculate the air side heat transfer rate:

$$
\begin{gathered}
\dot{Q}_{r e f}=\dot{m}_{r e f} \Delta h_{r e f} \\
\dot{Q}_{a}=\dot{m}_{a} \cdot\left(h_{a, \text { out }}-h_{a, \text { in }}\right)
\end{gathered}
$$

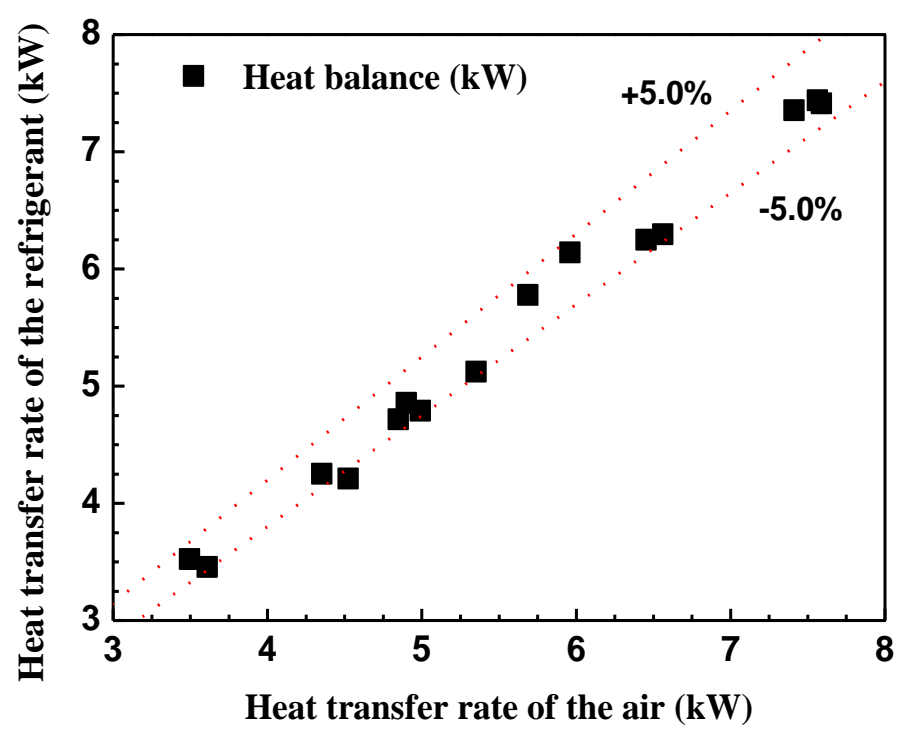

Figure 2. Heat Balance Between the Air Side and the Refrigerant Side 
The heat transfer rate of the air side was consistent with the heat transfer rate of the refrigerant side within $\pm 5 \%$, so the present experimental setup was found to be appropriate. The cooling COP (coefficient of performance) of the electrical air conditioning system was calculated by Equation (3).

$$
C O P=\frac{Q_{a}}{W_{c o m p}}
$$

\section{Results and Discussion}

\subsection{Cooling Performance Characteristics}

Figure 3 shows the COP and cooling capacity of electric-driven air conditioning system with developed tripe fluids heat exchanger in this study. The COP and cooling capacity for the evaporator side were tested with the variation of the inlet air temperature of the evaporator and compressor speed. In this study, the COP and cooling capacity varied from 2.0 to 4.1 and from $6.0 \mathrm{~kW}$ to $8.1 \mathrm{~kW}$ at air inlet temperature of $42{ }^{\circ} \mathrm{C}$ with the variation of compressor speed, respectively. On the other hand, those varied from 1.5 to 2.7 and from $3.0 \mathrm{~kW}$ to $4.4 \mathrm{~kW}$ at evaporator air inlet temperature of $27{ }^{\circ} \mathrm{C}$ along with the same compressor operating conditions. Constant operating conditions of applied two kinds of coolants, such as temperature and flow rate, as a condenser of triple fluids heat exchanger led to get increased COP and cooling capacity along with higher air inlet temperature for an evaporator. This showed opposite trend compared to conventional air conditioning system with the outdoor air to transfer heat from the refrigerant of the condenser.[19-21]

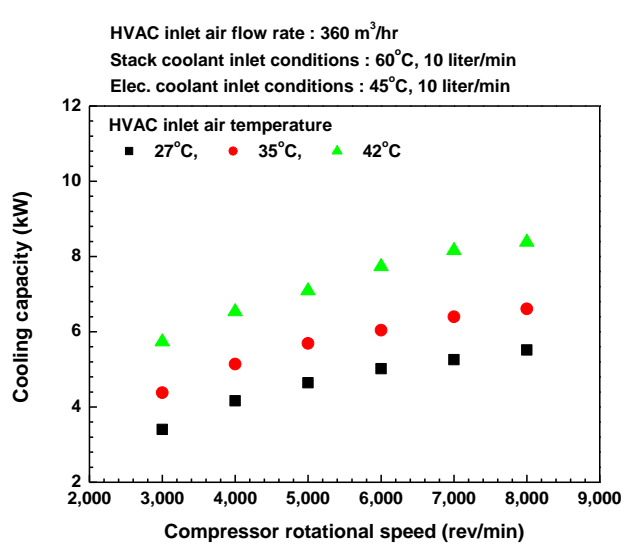

(a) Cooling Capacity

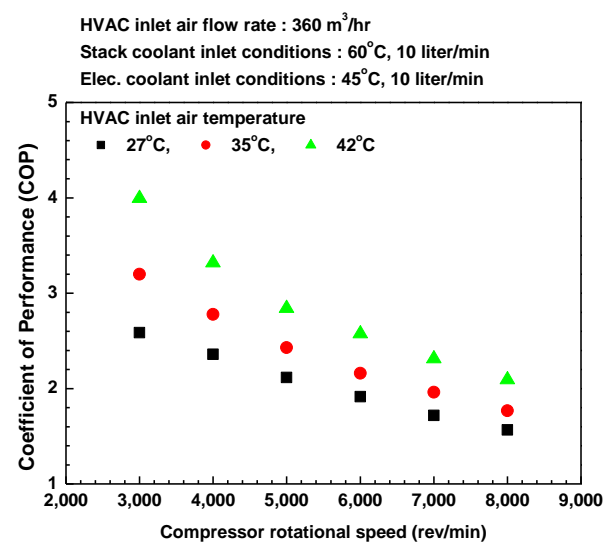

(b) Coefficient of Performance(COP)

Figure 3. Effects of the Inlet Air Temperature of Evaporator on the COP and Cooling Capacity with the Variation of Compressor Speeds 


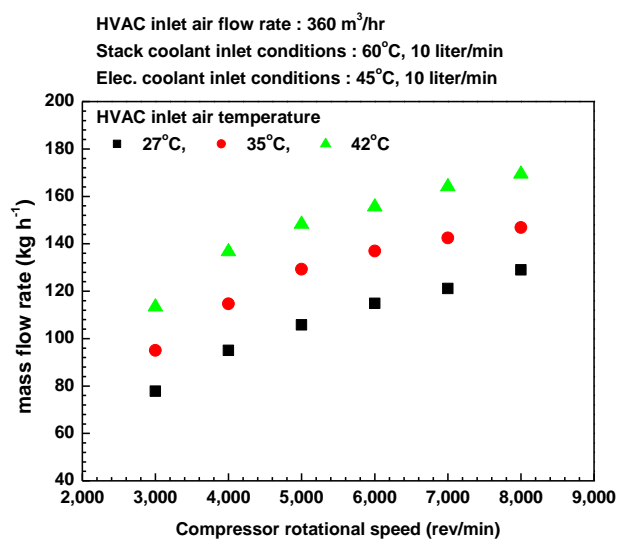

(a) Refrigerant Mass Flow Rate
HVAC inlet air flow rate : $360 \mathrm{~m}^{3} / \mathrm{h}$ Stack coolant inlet conditions : $60^{\circ} \mathrm{C}, 10$ liter $/ \mathrm{min}$ Elec. coolant inlet conditions : $45^{\circ} \mathrm{C}, 10 \mathrm{liter} / \mathrm{min}$

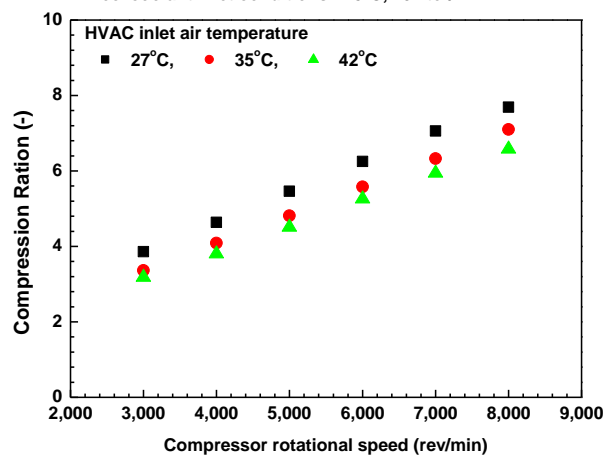

(b) Compression Ratio

Figure 4. Effects of the Inlet Air Temperature of Evaporator on the Refrigerant Mass Flow Rate and Compression Ratio with the Variation of Compressor Speeds

Figure 4 shows the refrigerant mass flow rate and compression ratio. Refrigerant mass flow rate increased with the increase of the evaporator inlet air temperature and compressor speed. With respect to compression ratio, the different aspect was shown than that of the refrigerant mass flow rate. Even though compression ratio increased with the compressor speed from 3.0 to 6.0 at air inlet temperature of $42{ }^{\circ} \mathrm{C}$, it decreased with the increase of the evaporator inlet air temperature. In case the outdoor air was applied to cool down the refrigerant as a different approach compared to this study, increasing the outdoor air temperature led to increase the compression ratio due to the increment of high-side pressure and relatively stable low-side pressure.[19-21]

\subsection{Triple Fluids Heat Exchanger's Performance Characteristics}

Figure 5 shows heat transfer rate for developed triple fluids heat exchanger as a condenser in cooling mode. Heat transfer rate increased along with increased compressor speed and air inlet temperature of the evaporator due to higher refrigerant mass flow rate. Triple fluids heat exchanger transferred heat between two kinds of coolants and the refrigerant. Heat transfer portion has different results along operating conditions, such as inlet air temperature variation of the evaporator and compressor speed variation. As the compressor speed increased, heat transfer portion for stack coolant side varied from $5.0 \%$ to $21.0 \%$. However, when the inlet air temperature of the evaporator increased, that varied from $5.0 \%$ to $5.8 \%$ due to path of the refrigerant, refrigerant temperature change. Furthermore, in the triple fluids heat exchanger, the refrigerant passed through stack coolant to electric coolant, therefore after the refrigerant flew stack coolant side path, the refrigerant temperature a bit lowered and temperature gap between refrigerant and electric coolant got smaller. Stack coolant portion of triple fluids heat exchanger was about $35.0 \%$ and electric device coolant portion of it was about $65.0 \%$ due to normal operating temperature, over $60{ }^{\circ} \mathrm{C}$ and under $50{ }^{\circ} \mathrm{C}$, respectively. 


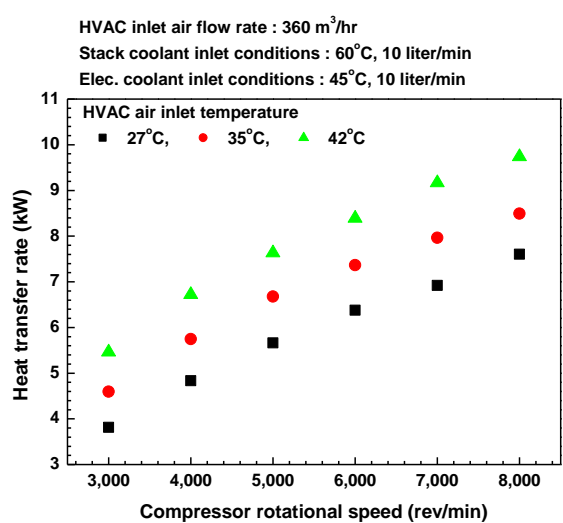

(a) Heat Transfer Rate

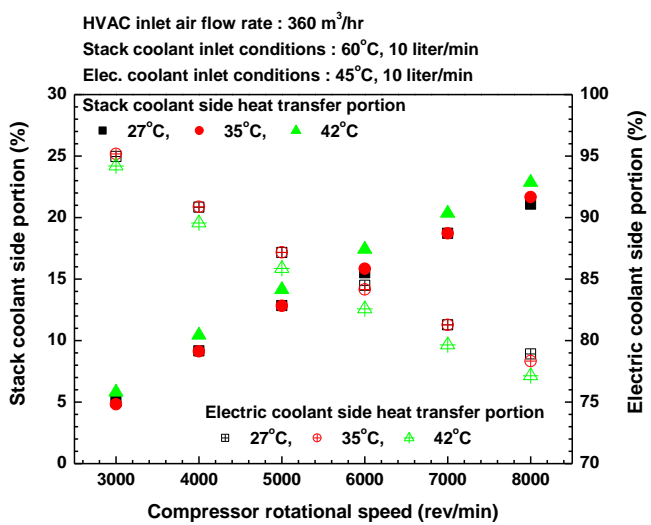

(b) Heat transfer portion among coolants

Figure 5. Heat Transfer Characteristics of the Triple Fluids Heat Exchanger with the Variation of Operating Conditions

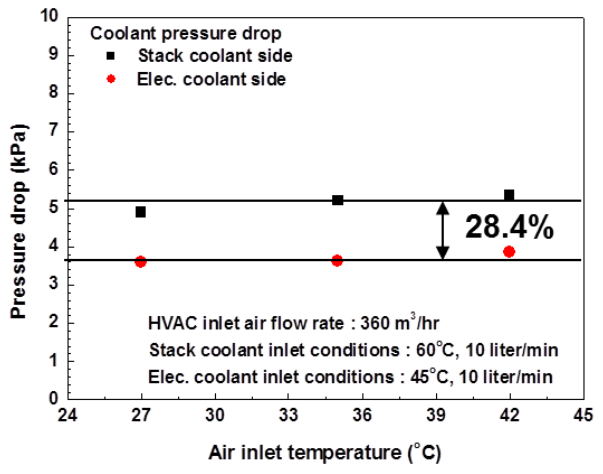

(a) Coolant Side

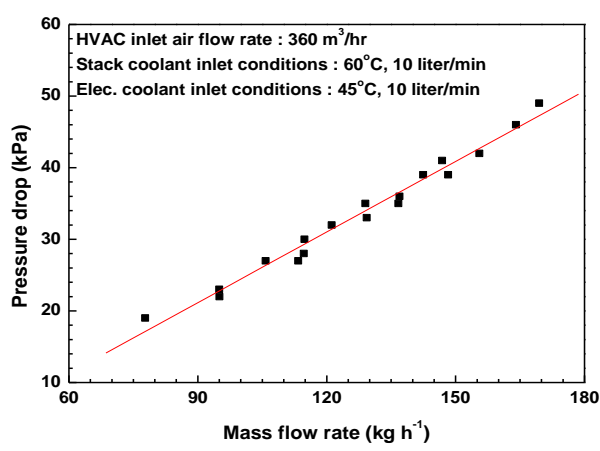

(b) Refrigerant Side

\section{Figure 6. Pressure Drop Characteristics of the Triple Fluids Heat Exchanger with the Variation of Operating Conditions}

Figure 6 shows pressure drop characteristics of the developed triple fluids heat exchanger with the variation of operating conditions, such as evaporator air inlet temperature and compressor speed. With respect to pressure drop, stack coolant side was higher than electric device coolant side by $28.4 \%$. The reason for higher pressure drop of stack coolant side, even less flow channel (35\% of total channels) and higher coolant temperature, seemed that because electric coolant's velocity of each channel with same coolant flow and more channels was faster than stack coolant, pressure drop of electric coolant side got higher. Refrigerant side pressure drop had first order equation along to the refrigerant flow rate like equation (4).

$$
\Delta P(k P a)=0.00329 \times \dot{m}\left(k g h^{-1}\right)-0.08407
$$




\section{Conclusions}

The cooling performance characteristics of electric-driven air conditioning system with developed triple fluids heat exchanger were experimentally investigated by varying the inlet air temperatures for evaporator side and compressor speeds. Experimental results showed that cooling capacity and coefficient of performance (COP) were sufficient to cover the cooling load of the automobile in hot weather conditions. The obtained results were as follows.

(1) COP and cooling capacity varied from 2.0 to 4.1 and from $6.0 \mathrm{~kW}$ to $8.1 \mathrm{~kW}$ at air inlet temperature of $42{ }^{\circ} \mathrm{C}$ with the variation of compressor speed, respectively. On the other hand, those varied from 1.5 to 2.7 and from $3.0 \mathrm{~kW}$ to $4.4 \mathrm{~kW}$ at evaporator air inlet temperature of $27^{\circ} \mathrm{C}$ along with the same compressor operating conditions.

(2) Refrigerant mass flow rate increased with the increase of the evaporator inlet temperature and compressor speed. Compression ratio decreased with the increase of the evaporator inlet temperature. However, compression ratio increased with the compressor speed from 3.0 to 6.0 at air inlet temperature of $42{ }^{\circ} \mathrm{C}$.

(3) With respect to triple fluid heat exchanger which has the role to transfer heat between two kinds of coolants and the refrigerant, stack coolant side was higher than electric device coolant side by $28.4 \%$. The refrigerant side pressure drop had first order equation along to the refrigerant flow rate.

Therefore, tested electric-driven air conditioning system using the triple fluids heat exchanger had sufficient cooling performance to cope with cooling load under various actual driving conditions. In the future, more researches about triple fluids heat exchanger will be performed and analyzed, especially, coolant side conditions variation.

\section{Acknowledgments}

This work was supported by a grant "Development of $3.5 \mathrm{~kW}$ heat pump system and components for the electric vehicle and high efficient operating technologies under low temperature (20142020104520)" from the Korea Institute of Energy Technology Evaluation and Planning.

\section{References}

[1] S.C. Kim, J. P. Won, Y. S. Park, T.W. Lim and M.S. Kim, "Performance evaluation of a stack cooling system using $\mathrm{CO} 2$ air conditioning system in fuel cell vehicle", International Journal of Refrigeration, vol. 32, (2009), pp. 75-80.

[2] S. Takahisa and I. Katsuya, "Air conditioning system for electric vehicle", Proceedings of SAE International Congress \& Exposition, (1996), 960688.

[3] B.X. Al-Alawi and T.H. Bradley, "Total cost of ownership, payback, and consumer preference modeling of plug-in hybrid electric vehicles", Applied Energy, vol. 103, (2013), pp. 488-506.

[4] A.S. Brouwer, T. Kuramochi, M. Broek, A. Faaij, "Fulfilling the electricity demand of electric vehicles in the long term future: an evaluation of centralized and decentralized power supply systems", Applied Energy, vol. 107, (2013), pp. 33-51.

[5] R. T. Doucette and M. D. McCulloch, "Modeling the prospects of plug-in hybrid electric vehicles to reduce CO2 emissions", Applied Energy, vol. 88, (2011), pp. 2315-2323.

[6] M. G. Lee, Y. K. Park, K.K. Jung and J. J. Yoo, "Estimation of fuel consumption using in-vehicle parameters", International Journal of u- and e- Service, Science and Technology, vol. 4, (2011), pp. 3746.

[7] H. Wang, Y. Liu, H. Fu and G. Li, "Estimation of state of charge of batteries for electric vehicles", International Journal of Control and Automation, vol. 6, (2013), pp. 185-194.

[8] D. W. Kim and M. Y. Lee, "Theoretical approach on the heating and cooling system design for an effective operation of Li-ion batteries for electric vehicles", Journal of the Korea Academia-Industrial Cooperation Society, vol. 15, (2014), pp. 2545-2552.

[9] J. Y. Jang, H. H. Bae, S. J. Lee and M. Y. Ha , "Continuous heating of an air-source heat pump during defrosting and improvement of energy efficiency", Applied Energy, vol. 110, (2013), pp. 9-16.

[10] K. A. Aikins, S. H. Lee and J. M. Choi, "Technology review of two-stage vapor compression heat pump system", International Journal of Air-Conditioning and Refrigeration, vol. 21, (2013).

[11] P. Byrne, J. Miriel and Y. Lent, "Experimental study of an air-source heat pump for simultaneous 
heating and cooling - Part 1: Basic concepts and performance verification”, Applied Energy, vol. 88, (2011), pp. 1841-1847.

[12] P. Byrne, J. Miriel and Y. Lent, "Experimental study of an air-source heat pump for simultaneous heating and cooling - Part 2: Dynamic behavior and two-phase thermosiphon defrosting technique", Applied Energy, vol. 88, (2011), pp. 3072-3078.

[13] D. Antonijevic and R. Heckt, "Heat pump supplemental heating system for motor vehicles", Journal of Automobile Engineering, vol. 218, no. 10, (2004), pp. 1111-1115.

[14] M. Hosoz and M. Direk, "Performance evaluation of an integrated automotive air conditioning and heat pump system", Energy Convers Manage, vol. 4, no. 47, (2006), pp. 545-549.

[15] J. H. Kim, Y. K. Min and B. S. Kim, "Is the PMV Index an indicator of human thermal comfort sensation", International Journal of Smart Home, vol. 7, no. 1, (2013), pp. 27-34.

[16] ANSI/ASME, "Measurement uncertainty", ANSI/ASME PTC 19-1-1985, Part 1, (1985)

[17] R.J. Moffat, "Uncertainty analysis in the planning of an experiment", J. Fluids Engineering, vol.107, (1985), pp. 173-178.

[18] ASHRAE Standard 116, "Methods of testing for seasonal efficiency of unitary air-conditioners and heat pumps", American Society of Heating, Refrigerating and Air-Conditioning Engineers Atlanta (GA), (1983).

[19] H.S. Lee, C.W. Cho, J.P. Won and M.Y. Lee, "Study on cooling performance characteristics of air conditioning system using R744 for a passenger vehicle", Journal of the Korea Academia-Industrial Cooperation Society, vol. 1, no. 12, (2011), pp. 1-7.

[20] H.S. Lee and M. Y. Lee, "Cooling performance characteristics on mobile air-conditioning system for hybrid electric vehicles", Advances in Mechanical Engineering, (2013), pp. 1-9.

[21] M.Y. Lee and D. Y. Lee, "Review on conventional air conditioning, alternative refrigerants and $\mathrm{CO}_{2}$ heat pumps for vehicles", Advances in Mechanical Engineering, (2013), pp. 1-15.

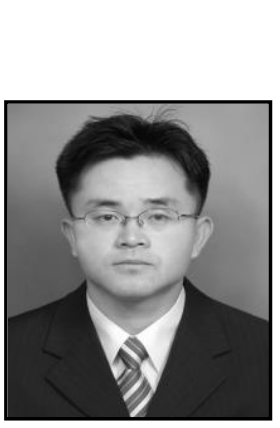

\section{Authors}

\section{Hoseong Lee, First Author}

- Feb. 2006: Dept. of Mech. Eng., Korea Univ. (Master's Degree)

- Aug. 2007: Researcher of the Hyundai Motors

- Sep. 2007: Current : Thermal management system research center, KATECH.

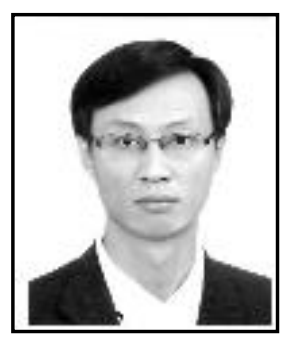

\section{Jongphil Won, Second Author}

- Feb. 1992: Dept. of Mech. Eng., Ky-unghee Univ. (Master's degree)

- Feb. 1999: Dept. of Mech. Eng., Ky-unghee Univ. (Ph.D)

- Sep. 2007: Current : Thermal management system research center, KATECH.

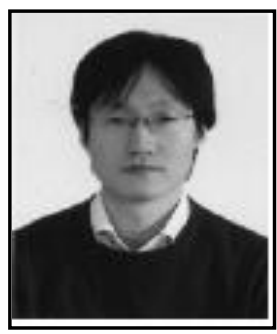

\section{Chungwon Cho, Third Author}

- Feb. 2005 : Dept. of Mech. Eng., KAIST. (Ph.D)

- April 2006 : New Revewable energy development team, Doo-san heavy I\&C.

- Feb. $2011 \sim$ Current : Thermal management system research center, KATECH. 


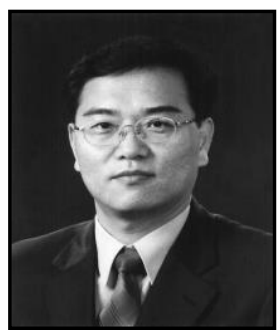

Yongchan Kim, Corresponding Author

- Aug. 1993 : Dept. of Mech. Eng., Texas A\&M Univ. (Ph.D)

- Mar. $1995 \sim$ Current : Professor, Korea Univ. Korea.

- Jul. 2006 Feb. 2010 : Chairman, Dept. of Mech. Eng., Korea Univ. 
International Journal of Control and Automation Vol. 9 No. 5 (2016) 